\title{
Neuroprotective effects of bis(7)-tacrine against glutamate-induced retinal ganglion cells damage
}

Jia Hua Fang ${ }^{1,2}$, Xing Hua Wang ${ }^{1}$, Zhi Rong Xu' ${ }^{1}$ Fa Gang Jiang ${ }^{1 *}$

\begin{abstract}
Background: Glutamate-mediated excitotoxicity, primarily through N-methyl-D-aspartate (NMDA) receptors, may be an important cause of retinal ganglion cells (RGCs) death in glaucoma and several other retinal diseases. Bis(7)tacrine is a noncompetitive NMDA receptors antagonist that can prevent glutamate-induced hippocampal neurons damage. We tested the effects of bis(7)-tacrine against glutamate-induced rat RGCs damage in vitro and in vivo.

Results: In cultured neonatal rats RGCS, the MTT assay showed that glutamate induced a concentration- and timedependent toxicity. Bis(7)-tacrine and memantine prevented glutamate-induced cell death in a concentrationdependent manner with IC50 values of $0.028 \mu \mathrm{M}$ and $0.834 \mu \mathrm{M}$, respectively. The anti-apoptosis effects of bis(7)tacrine were confirmed by annexin V-FITC/PI staining. In vivo, TUNEL analysis and retrograde labeling analysis found that pretreatment with bis(7)-tacrine $(0.2 \mathrm{mg} / \mathrm{kg})$ induced a significant neuroprotective effect against glutamate-induced RGCs damage.

Conclusions: Our results showed that bis(7)-tacrine had neuroprotective effects against glutamate-induced RGCs damage in vitro and in vivo, possibly through the drug's anti-NMDA receptor effects. These findings make bis(7)tacrine potentially useful for treating a variety of ischemic or traumatic retinopathies inclusive of glaucoma.
\end{abstract}

\section{Background}

Glutamate is a major excitatory neurotransmitter in the central nervous system, including the retina[1,2]. It is released by the presynaptic cells and acts on $\mathrm{N}$-methylD-aspartate (NMDA), $\alpha$-amino-3-hydroxy-5-methyl-4isoxazolepropionic acid (AMPA), and kainite (KA) receptors [3]. If excessive amounts of glutamate are released or if glutamate clearance is insufficient, neuronal death will result in a process known as excitotoxicity. The glutamate receptor-mediated excitotoxicity has been associated to various diseases of the brain and eye, which include Alzheimer's disease[4], retinal ischemia $[5,6]$ and glaucoma[7,8]. Although retinal ganglion cells (RGCs) express all of three receptor subtypes, the glutamate toxicity is primarily mediated by NMDA receptors [9-11].

Glaucoma, a neurodegenerative disease[12], is associated with selective death of retinal ganglion cells [13]. The disease is characterized by an elevation in intraocular pressure (IOP), which leads to increased glutamate

\footnotetext{
* Correspondence: fgjiang@hotmail.com

'Department of Ophthalmology, Union Hospital, Tongji Medical College, Huazhong University of Science and Technology, Wuhan 430022, China
}

levels [14]. Vitreal glutamate levels are elevated in dogs [15] and humans with primary glaucoma [16], and also in monkeys with experimentally induced chronic glaucoma[16]. Lowering IOP is the current main treatment for glaucoma, yet disease progression continues to occur even in patients with significant IOP reduction[17]. Therefore lowering IOP is inadequate for glaucoma patients [12,18]. Efforts have been made to attempt to discover appropriate drugs or chemicals (neuroprotectants) that can be taken orally to slow down retinal ganglion cell death and have negligible side-effects [19]. Memantine is an uncompetitive NMDA receptor antagonist which is prescribed for the treatment of Alzheimer's disease [20]. However, two recent parallel clinical trials conducted to test the efficacy of memantine as a neuroprotectant for glaucoma were unsuccessful[21]. The results of the trials showed that memantine had no significant effects in preserving visual function.

Until now, there has been no neuroprotective agent indicated for the treatment of glaucoma. A neuroprotectant that has a single mode of action like memantine has a limited positive effect in slowing down ganglion cell death [19]. Pharmacological agents that simultaneously affect 
multiple biological mechanisms are consequently desired. This has been referred to as the "cocktail" approach [22]. One-drug-multiple-targets approach in the treatment of neurodegenerative diseases is possible way forward $[19,23]$.

Beside NMDA receptor antagonism, other strategies have been investigated in the development of neuroprotective therapies, which include voltage-dependent calcium channel blockade [24,25], nitric oxide synthase (NOS) inhibition [26,27], and so on. Bis(7)-tacrine (1,7N-heptylene-bis-9,9'-amino-1,2,3,4-tetrahydroacridine), a dimeric acetylcholinesterase (AChE) inhibitor derived from anti-Alzheimer's drug tacrine, possesses remarkable neuroprotective activities through concurrent inhibition of AChE [28,29], NMDA receptor[30] and nitric oxide synthase [31,32]. Moreover, bis(7)-tacrine attenuates neuronal apoptosis by regulating L-type voltagedependent calcium channels(VDCCs) [33]. Recent studies showed that bis(7)-tacrine prevented glutamateinduced excitotoxicity by selectively inhibiting NMDA receptors in primary cultured cerebellar granule neurons (CGNs), without the involvement of the other two ionotropic glutamate receptors, AMPA receptor and KA receptor [30,34,35].

Based on these evidence, we hypothesis that bis(7)tacrine attenuate glutamate-induced retinal ganglion cells damage through the blockade of NMDA receptors. We tested the effect of bis(7)-tacrine in two models of glutamate excitotoxity, RGCs in culture with glutamate and intravitreal injection of glutamate. The results showed that bis(7)-tacrine reduced glutamate-induced retinal ganglion cells damage in vitro and in vivo.

\section{Results}

\section{Identification of cultured RGCs}

The purity of isolated RGCs was assessed by fluorescent microscope (IX71, Olympus, Japan) using a UV filter that permitted the visualization of fluorogold fluorescence (Fig. 1). RGCs were labeled by fluorogold in a retrograde manner. After a two-step immunopanning procedure, approximately $87.8 \%(1896 / 2158$ cells $)$ of the collected cells were labeled by fluorogold. Because it is difficult to obtain uniform labeling, a small number of RGCs were probably not identified by retrograde transport, and the purity of the preparations was therefore underestimated.

\section{Bis(7)-tacrine prevents glutamate-induced cell death more potently than memantine}

Glutamate toxicity was found to be concentration- and time-dependent, which was consistent with previous reports[9,36]. At 3 days in vitro, RGCs were exposed continuously to 25-300 $\mu \mathrm{M}$ glutamate for $24 \mathrm{~h}$ and 50 $\mu \mathrm{M}$ glutamate alone at different times. Cell viability was measured by MTT assay. Glutamate induced a
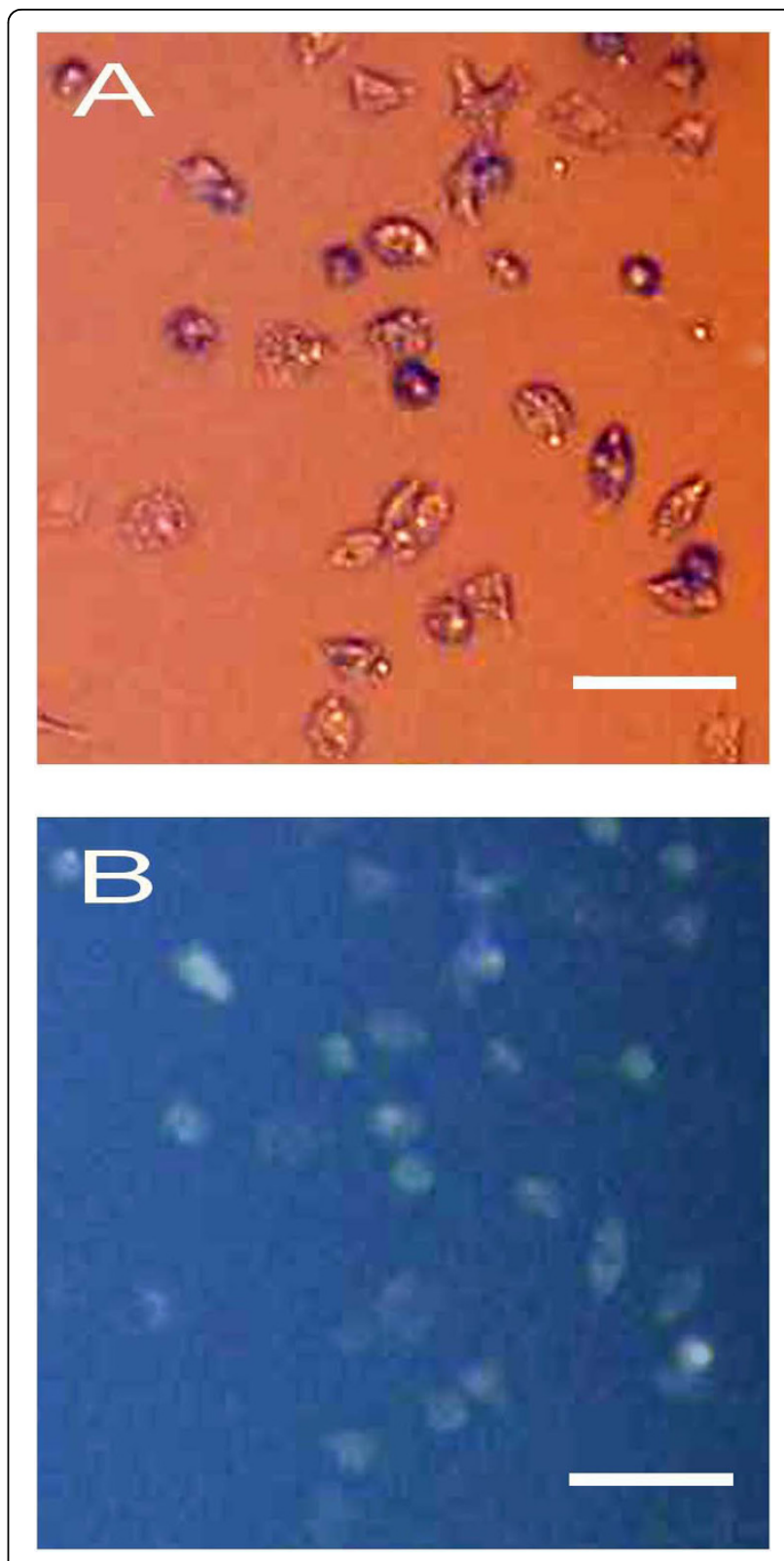

Figure 1 Identification of cultured rat RGCs. Phase contrast image (A) and fluorescence image (B) of RGCs purified from a 5-day-old rat that had received injections of fluorogold into the superior colliculi 1 day after birth. The cells were cultured for 1 days under control conditions. Scale bar, $50 \mu \mathrm{m}$.

concentration- dependent loss in neuronal viability starting from $25 \mu \mathrm{M}$ and peaking at $300 \mu \mathrm{M}$ (Fig. 2A). Glutamate at $50 \mu \mathrm{M}$ induced a time-dependent neuronal death starting at $12 \mathrm{~h}$ and culminating at $36 \mathrm{~h}$ (Fig. 2B). RGCs were pretreated with $1 \mu \mathrm{M}$ bis(7)-tacrine for $2 \mathrm{~h}$ and exposed to different concentrations of glutamate for $24 \mathrm{~h}$. With the increase of glutamate concentrations, the neuroprotective effects of bis(7)-tacrine gradually decreased and completely lost when RGCs were exposed 


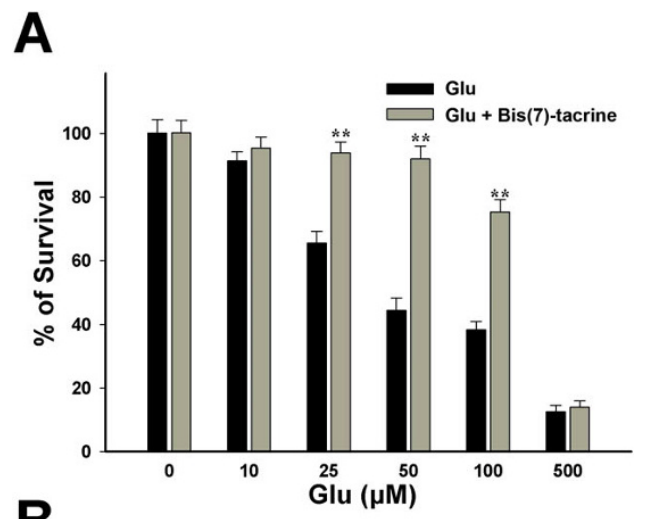

B

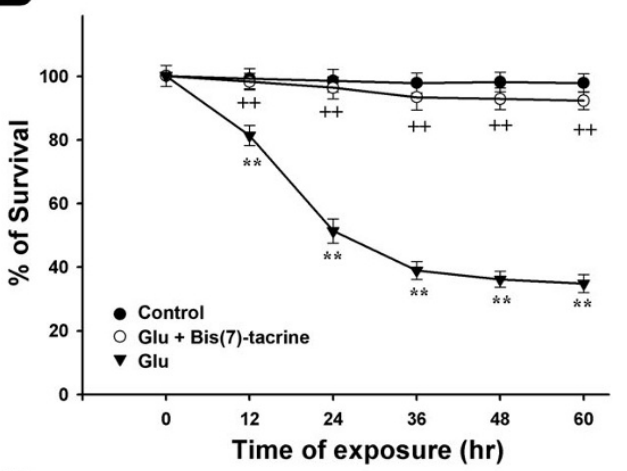

C

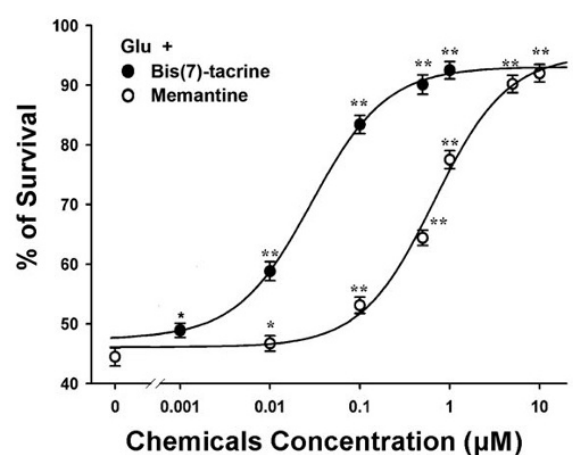

Figure 2 Glutamate (Glu) induces a concentration- and time-dependent changes and bis(7)-tacrine is more potent than memantine in preventing the excitotoxicity of glutamate in the MTT assay. A, at 3 days in vitro, cultured RGCs were exposed to $1 \mu \mathrm{M}$ bis(7)-tacrine for $2 \mathrm{~h}$ before the addition of glutamate at the different concentrations indicated. Cell viability was measured at $24 \mathrm{~h}$ by MTT assay. B, compared with normal neurons, RGCs were preincubated with or without $1 \mu \mathrm{M}$ bis(7)tacrine for $2 \mathrm{~h}$ and then exposed to $50 \mu \mathrm{M}$ glutamate at different times indicated. Cell viability was measured at the indicated times. $C$, graph plotting percentage of neuron survival as a function of concentrations of bis(7)-tacrine $(\bullet)$ and memantine $(\mathbb{\otimes})$. RGCs were pretreated with bis(7)-tacrine (0.001-1 $\mu \mathrm{M})$ or memantine (0.01-10 $\mu \mathrm{M})$ for $2 \mathrm{~h}$ before the addition of $50 \mu \mathrm{M}$ glutamate. At $24 \mathrm{~h}$ after the challenges, cell viability was measured. All of the data, expressed as percentages of the corresponding control, were means \pm SEM of three separate experiments. ${ }^{*} P<0.05$, ${ }^{* *} P<0.01$ versus glutamate group in $A$ and $C$ or versus control at the same time in $B$. $++P<0.01$ versus glutamate group at the same time in $B$. to over $300 \mu \mathrm{M}$ glutamate (Fig. 2A). Bis(7)- tacrine at $1 \mu \mathrm{M}$ retained its neuroprotective effects for at least $60 \mathrm{~h}$ after glutamate stimulation (Fig. 2B). RGCs were pretreated with the gradually increasing concentrations of bis(7)-tacrine or memantine for $2 \mathrm{~h}$ and then exposed to $50 \mu \mathrm{M}$ glutamate for $24 \mathrm{~h}$. It was found that bis(7)tacrine and memantine prevented glutamate-induced cell death in a concentration-dependent manner with IC50 values of $0.028 \mu \mathrm{M}$ and $0.834 \mu \mathrm{M}$, respectively (Fig. 2C). Bis(7)-tacrine inhibited the glutamate-induced cell death more potently than memantine.

\section{Bis(7)-tacrine reduces glutamate-induced apoptosis of RGCs in vitro}

The anti-apoptotic effects of bis(7)-tacrine were studied using an Annexin-V FITC/PI assay. The results demonstrated that $50 \mu \mathrm{M}$ glutamate induced apoptosis in a time-dependent manner and bis(7)-tacrine could prevent glutamate-induced apoptosis (Fig. 3). Although the initial $6 \mathrm{~h}$ of glutamate exposure did not change the percentage of apoptotic cells relative to the control group, there were marked increases in the percentage of apoptotic cells after $12 \mathrm{~h}(18.48 \pm 2.76 \%$; $<<0.05)$ and $24 \mathrm{~h}(45.12 \pm 6.15 \% ; \mathrm{p}<0.05)$. Bis(7)-tacrine inhibited glutamate-induced damage to RGCs in a concentrationdependent manner. At $12 \mathrm{~h}$, bis(7)-tacrine at $0.01 \mu \mathrm{M}$ has a tendency to reduce glutamate-induced damage ( $\mathrm{P}>0.05)$, but bis(7)-tacrine $(0.1 \mu \mathrm{M}, 1 \mu \mathrm{M})$, as well as memantine $(1 \mu \mathrm{M}, 10 \mu \mathrm{M})$, decreased the percentage of apoptotic cells to $9.78 \pm 0.97 \%, 7.92 \pm 1.14 \%, 13.92 \pm$ $2.98 \%, 8.28 \pm 1.87 \%$ respectively (all p $<0.05$ ). At $24 \mathrm{~h}$, all the concentrations of two drugs, bis(7)-tacrine $(0.01$ $\mu \mathrm{M}, 0.1 \mu \mathrm{M}, 1 \mu \mathrm{M})$ and memantine $(1 \mu \mathrm{M}, 10 \mu \mathrm{M})$, reduced effectively the percentage of apoptotic cells, but only with bis(7)-tacrine $(1 \mu \mathrm{M})$ show no significant increase in the percentage of apoptotic cells in comparison with control group.

\section{Bis(7)-tacrine reduces glutamate-induced apoptosis of RGCs in vivo}

Apoptotic changes in the retina were assessed by the TUNEL method. Little TUNEL positivity was observed in the control (PBS-injected) group (Fig. 4A). However, at $18 \mathrm{~h}$ after glutamate was injected into the eyes, prominent TUNEL-positive cells were found in the ganglion cell layer(GCL) and the inner nuclear layer (INL) (Fig. 4B). The density of TUNEL-positive cells in GCL was $64.87 \pm 8.83$ cells $/ \mathrm{mm}$ in the glutamate group whereas it was $54.50 \pm 8.15 / \mathrm{mm}$ in the animals receiving bis(7)-tacrine at $0.1 \mathrm{mg} / \mathrm{kg}(\mathrm{P}<0.05)$ and $42.87 \pm$ $7.82 / 0.5 \mathrm{~mm}$ when the dose of bis(7)-tacrine was 0.2 $\mathrm{mg} / \mathrm{kg}(\mathrm{P}<0.01)$. Compared with the glutamate group, there was no statistically significant reduction when animals receiving bis $(7)$-tacrine at $0.05 \mathrm{mg} / \mathrm{kg}(\mathrm{P}>0.05)$. 


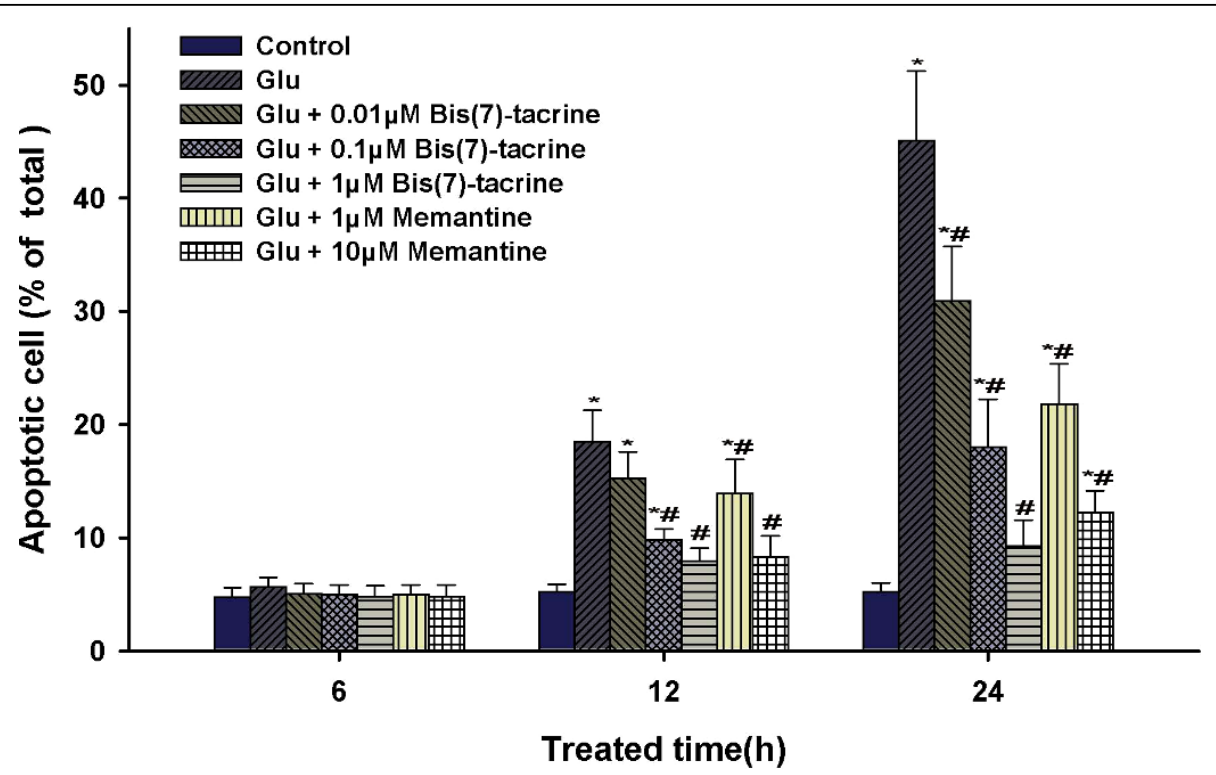

Figure 3 Bis(7)-tacrine reduces glutamate(Glu)-induced apoptosis of RGCs in vitro. RGCs were cultured with and without glutamate for 6-24 $\mathrm{h}$ in the presence or absence of bis(7)-tacrine (0.01-1 $\mu \mathrm{M})$ or memantine (1-10 $\mu \mathrm{M})$. Percentage of apopotic cells was detected by Annexin-V FITC/PI staining by flow cytometry. Apoptotic cells included Annexin V(+)/PI(-) and Annexin V(+)/PI(+) cells. Results were expressed as the means \pm SEM of 7 independent experiments. ( ${ }^{*} \mathrm{P}<0.05$ as compared to the control group for each time point; \# $\mathrm{P}<0.05$ as compared to the glutamate group for each time point).

The results showed that bis(7)-tacrine rescued these neurons from apoptosis which was induced by glutamate in a dose-dependent manner. Memantine $(10 \mathrm{mg} /$ $\mathrm{kg}, 20 \mathrm{mg} / \mathrm{kg}$ ) showed the same protective effects as bis (7)-tacrine $(0.2 \mathrm{mg} / \mathrm{kg})$ (Fig. 4E).

\section{Bis(7)-tacrine protect RGCs in experiments using retrograde labeling of RGCs}

The GCL is composed of about equal numbers of RGCs and displaced amacrines[37]. To ensure accurate identification of RGCs, we retrogradely labeled the RGCs in rats with fluorogold allowing us to selectively label greater than $99 \%$ of the RGCs. In PBS-injected eyes without glutamate, the mean density of RGCs was $2196.6 \pm 155.0$ cells $/ \mathrm{mm}^{2}(\mathrm{n}=6)$ (Fig. 5A). Fifteen minutes after intraperitoneally injection of bis(7)-tacrine $(0.05,0.1,0.2 \mathrm{mg} / \mathrm{kg})$, memantine $(5,10,20 \mathrm{mg} / \mathrm{kg})$ or PBS, $20 \mathrm{nmol}$ glutamate was injected intravitreally into the same animals. At 7 days after glutamate injection, the mean densities of the RGCs in control (PBSinjected) and experimental (0.05, 0.1, $0.2 \mathrm{mg} / \mathrm{kg}$ bis(7)tacrine and $5,10,20 \mathrm{mg} / \mathrm{kg}$ memantine) eyes were $676.5 \pm$ 49.6, $729.3 \pm 50.5,853.0 \pm 102.0,1284.6 \pm 99.0,697.3 \pm$ $42.4,770.0 \pm 85.2,1148.2 \pm 105.0$ cells $/ \mathrm{mm}^{2}(\mathrm{n}=6)$ (Fig. 5E), respectively, and the different was statistically significant (PBS vs $0.1 \mathrm{mg} / \mathrm{kg}$ bis(7)-tacrine, $\mathrm{P}=0.038$; PBS vs $0.2 \mathrm{mg} / \mathrm{kg}$ bis(7)-tacrine, $\mathrm{P}<0.01$; PBS vs $20 \mathrm{mg} /$ $\mathrm{kg}$ memantine, $\mathrm{P}<0.01)$. These data showed that both of bis(7)-tacrine and memantine possessed neuroprotective effects against glutamate-induced RGCs death, and bis (7)-tacrine $(0.2 \mathrm{mg} / \mathrm{kg})$ had the same effects as memantine $(20 \mathrm{mg} / \mathrm{kg})$.

\section{Discussion}

Glutamate excitotoxicity is thought to contribute to a broad variety of neurological diseases, including Alzheimer's disease and glaucoma. In retina tissues, the predominant form of glutamate neurotoxicity is mediated by overstimulation of the NMDA subtype of glutamate receptors, which in turn causes an increase of $\mathrm{Ca}^{2+}$ influx, followed by cell death $[5,9,38]$. Recent research demonstrated that bis(7)-tacrine prevented glutamateinduced cerebellar granule neurons (CGNs) apoptosis through directly blocking NMDA receptors [30,34]. We show here that bis(7)-tacrine provided in vitro and in vivo neuroprotective effects on glutamate-induced RGCs damage. Although the cytoprotective actions of bis(7)tacrine have previously been observed in brain neurons under excitotoxic/ischemic conditions[23,30,34,39], to our knowledge, this is the first report to elucidate the neuroprotective action of bis(7)-tacrine on RGCs in response to glutamate excitotoxicity.

Some researches have reported that RGCs are highly susceptible to glutamate toxicity in vitro and in vivo $[9,38,40]$. First of all, we explored the in vitro effectiveness of bis(7)-tacrine against glutamate-induced RGCs damage. In a previous report, glutamate toxicity was concentration-dependent with a calculated $\mathrm{EC}_{50}$ of 30.8 

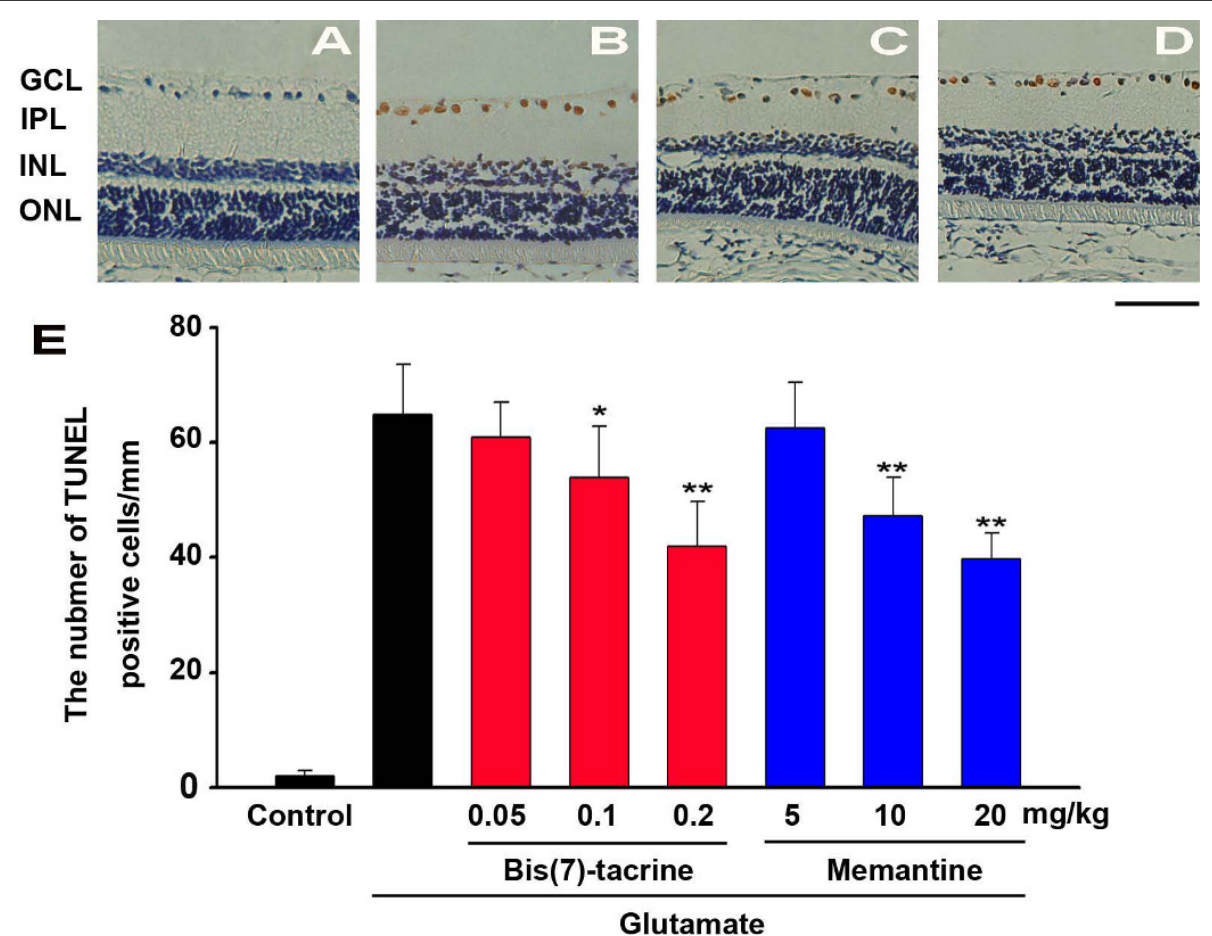

Glutamate

Figure 4 Bis(7)-tacrine reduces glutamate(Glu)-induced apoptosis of RGCs in vivo. Eyes were enucleated at $18 \mathrm{~h}$ after intravitreal injection of glutamate(Glu) (20 nmol) or vehicle. TUNEL staining was performed and TUNEL-positive cells were counted in GCL. (A) A representative photograph of retina in the vehicle group. (B) A representative photograph of retina in the glutamate group. (C \& D) A representative photograph of retina in the glutamate group with peritoneal injection of bis(7)-tacrine $(0.2 \mathrm{mg} / \mathrm{kg})(\mathrm{C})$ or memantine(20 mg/ $/ \mathrm{kg})(\mathrm{D})$. (E) The number of TUNEL-positive cells in GCL was counted. Each column represents means \pm SEM $(n=6)$. ${ }^{*} P<0.05$, ** $<0.01$ versus glutamate group alone. GCL: ganglion cell layer, IPL: inner plexiform layer, INL: inner nuclear layer, ONL: outer nuclear layer. Scale bar, $50 \mu \mathrm{m}$.

$\mu \mathrm{M}[9]$. In our study, the MTT assays have shown that cultured RGCs are highly sensitive to $24 \mathrm{~h} 50 \mu \mathrm{M}$ glutamate treatment, which produces $50 \%$ or greater cell death. Furthermore, bis(7)-tacrine, like the NMDA receptor antagonist memantine, has been confirmed to attenuate the cytotoxic effect of glutamate. As memantine showed affinity and potency comparable to those of bis(7)-tacrine in blocking the NMDA receptor [39], we chose memantine as the positive control in this study. The minimal effective concentration of bis(7)-tacrine against glutamate excitotoxicity was approximately 0.01 $\mu \mathrm{M}$. The combination of data from the MTT assays and the Annexin V-FITC/PI assays, provided strong evidence that bis(7)-tacrine was significantly more potent than memantine in inhibiting glutamate-induced cell damage. This finding was similar to previous reports in cultured rat cortical neurons[34].

Next, we verified the neuroprotective effects of bis(7)tacrine in animal models of glutamate-induced retinal injury. The pharmacokinetic research in the body of the rat showed that bis(7)-tacrine was rapidly and widely distributed to its target tissues such as brain[41,42]. In a model of acute focal cerebral ischemic insults in MCAO rats, bis(7)-tacrine at doses of $0.1 \mathrm{mg} / \mathrm{kg}$ and $0.2 \mathrm{mg} / \mathrm{kg}$ significantly reduced ischemic impairment in vivo[23]. In the current study, two animal assays showed that bis (7)-tacrine $(0.2 \mathrm{mg} / \mathrm{kg})$ protected RGCs from glutamate excitotoxicity, while bis(7)-tacrine $(0.05 \mathrm{mg} / \mathrm{kg})$ had no significant neuroprotective effects.

We cannot definitively state that bis(7)-tacrine was neuroprotective for retinal ganglion cells alone. In retina tissues, several cells express NMDA receptors, such as RGCs and displaced amacrine cells[43] in the retinal ganglion cell layer (GCL)and bipolar cells[44] in the inner nuclear layer (INL). These cells are susceptible to excitotoxic cell death, we did not differentiate between retinal ganglion cells and other cells.

Neuroprotection was initially studied as a treatment strategy for various neurological disorders including stroke, dementia, multiple sclerosis, Alzheimer's disease and glaucoma. Despite successful preclinical cell culture and animal model experiments, most of these therapies were not successful at the clinical stage of testing because of either unacceptable side effect profiles or a lack of efficacy $[12,45,46]$. High affinity NMDA receptor antagonists such as MK-801 are undesirable as they entail nonselective inhibition of tonic glutamate activity as well as phasic physiological NMDA receptor function 

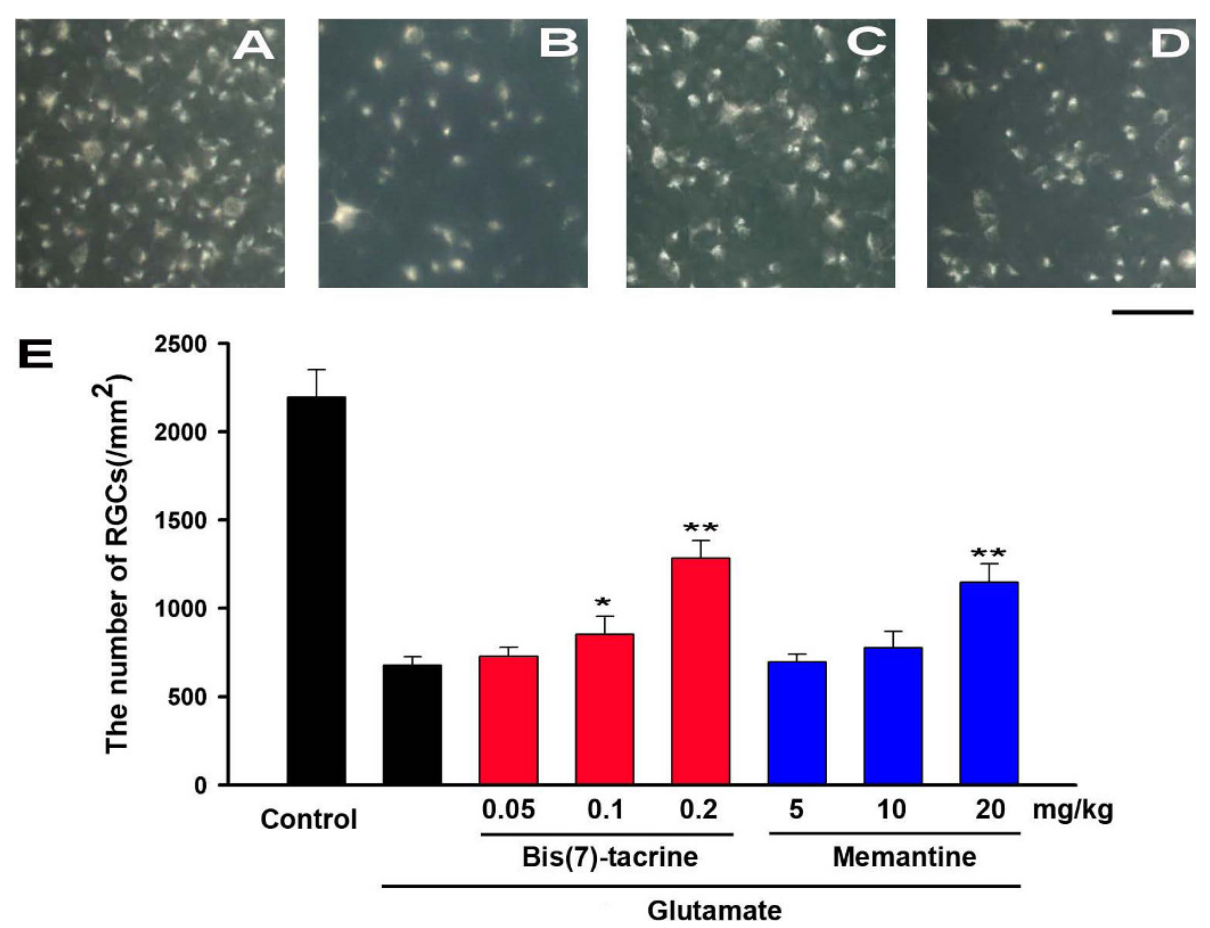

Figure 5 Effect of bis(7)-tacrine on RGCs following intravitreal injection of glutamate(Glu) (20 nmol). (A) A representative photograph of RGCs labeled with fluorogold injected into the superior colliculus in normal retina. (B) A representative photograph of fluorogold -labeled RGCs 7 days after intravitreal injection of glutamate. (C \& D) A representative photograph of fluorogold -labeled RGCs 7 days after intravitreal injection of glutamate with daily peritoneal injection of bis(7)-tacrine $(0.2 \mathrm{mg} / \mathrm{kg})(\mathrm{C})$ or memantine $(20 \mathrm{mg} / \mathrm{kg})(\mathrm{D})$. (E) The number of RGCs was counted. Each column represents means $\pm \operatorname{SEM}(n=6)$. ${ }^{P} P<0.05$, ${ }^{*} \mathrm{P}<0.01$ versus glutamate group alone. Scale bar, $50 \mu \mathrm{m}$.

[47]. Memantine is a moderate affinity, uncompetitive NMDA receptor antagonist prescribed for the treatment of moderate to severe Alzheimer's disease [48,49]. However, recent clinical findings showed that there was no clear benefit after glaucoma patients received memantine; thereby it was suggested that neuroprotectants with multiple modes of actions were likely to reveal clearer results than was found for memantine [19].

The preclinical studies demonstrated that bis(7)tacrine had low toxicity in animal models[50], and bis (7)-tacrine possessed multiple physiological activities including anti-NMDA receptors, anti-AChE, anti-Ltype-voltage-dependent calcium channels(VDCCs), antinitric oxide synthase (NOS) signaling and the regulation of the downstream signal of NMDA receptors $[28,30,32,33,51]$. In the present study, bis(7)-tacrine prevented glutamate-induced RGCs damage possibly by inhibiting NMDA receptors. At this point, electrophysiology studies will be needed to verify the blocking kinetics of bis(7)-tacrine on three glutamate receptors in the purified RGCs. What's more, further calcium imaging studies will be required to determine the role of calcium permeation through NMDA receptors and to determine if intracellular calcium is involved in triggering neuroprotection or inhibiting glutamate excitotoxicity. Besides inhibiting NMDA receptors, the other effects of bis(7)-tacrine on RGCs deserves further study.

\section{Conclusions}

In conclusion, our experiments have demonstrated that bis(7)-tacrine can provide neuroprotection against glutamate-induced retinal ganglion cells damage in vitro and in vivo. The effects may be achieved through inhibitions of NMDA receptors. This neuroprotective effects of bis (7)-tacrine may lead to a novel approach for the treatment of retinopathies, such as glaucoma.

\section{Methods}

\section{Animals and reagents}

Sprague-Dawley(SD) rats, including 1-3 days rats and adult male rats, were obtained from the Animal Center in Tongji Medical College, Huazhong University of Science and Technology, and were housed in the animal facility under standard conditions of room temperature and a 12:12 h light-dark cycle with free access to food and water. All animal experiments followed the guidelines for the care and use of animals established by Tongji Medical College, Huazhong University of Science and Technology and adhered to the tenets of the 
Declaration of Helsinki. Bis(7)-tacrine was purchased from Cayman Chemical Co.(USA). Fluorogold was purchased from Biotium (Hayward, USA). Unless noted, all other reagents were obtained from Sigma (St. Louis, MO, USA).

\section{Cell culture and purification of RGCs}

RGCs from retinas of 1-3 days rats were purified by a two-step immunopanning procedure. Briefly, the retinal tissue was dissociated into single cells in EMEM (Gibco, China) containing $15 \mathrm{U} / \mathrm{ml}$ papain and $70 \mathrm{U} / \mathrm{ml}$ collagenase. The dissociated cells were incubated in a polypropylene tube coated with an anti-rat macrophage monoclonal IgG (Chemicon International, Inc, CA, USA) to exclude macrophages, and then incubated in a tube coated with an anti-rat Thy 1.1 monoclonal IgG (Chemicon International, Inc, CA, USA). The tube was gently washed with PBS for five times, and adherent RGCs were collected by centrifugation at $600 \mathrm{~g}$ for 5 minutes.

Before the examinations of effects of bis(7)-tacrine on RGCs, a preliminary study was conducted to determine purity of RGCs after the two-step immunopanning procedure. After 1-day-old rats were anesthetized by intraperitoneal injection with $10 \%(\mathrm{w} / \mathrm{v})$ chloral hydrate $(350$ $\mathrm{mg} / \mathrm{kg}$ ), RGCs were labeled in a retrograde manner by injecting $4 \%$ fluorogold into the superior colliculi. Four days later, after this immunopanning method, approximately $87.8 \%(1896 / 2158$ cells) of the collected cells were labeled by fluorogold. Next, in further examinations of effects of bis(7)-tacrine on RGCs, RGCs were used from rats without fluorogold injection and grown in serum-free medium (Gibco-China), containing $1 \mathrm{mM}$ glutamine, $10 \mu \mathrm{g} / \mathrm{mL}$ gentamicin, B27 supplement (1:50), $40 \mathrm{ng} / \mathrm{mL}$ each of BDNF and CNTF, and $5 \mu \mathrm{M}$ forskolin. RGCs were cultured in a $\mathrm{CO}_{2}$ incubator (Thermo Lab 2300, USA) with $5 \% \mathrm{CO}_{2}$ at $37^{\circ} \mathrm{C}$. Before seeding, the plates were coated with poly-D-lysine (PDL, $70 \mathrm{kDa}, 10 \mu \mathrm{g} / \mathrm{ml}$ ) at room temperature followed by overnight incubation with mouse laminin. RGCs were cultured for 3 days and then exposed them to glutamate and/or bis(7)-tacrine for MTT assay or annexin-V FITC/PI assay.

\section{Measurement of neurotoxicity}

The percentage of surviving RGCs in the presence of bis (7)-tacrine and/or glutamate was estimated by determining the activity of mitochondrial dehydrogenases with 3 (4,5-dimethylthiazol-2-yl)-2.5-diphenyltetrazolium bromide (MTT) assay [30]. Cells were seeded at a density of 5000 cells/well in 96-well plates. The assay was performed according to the specifications of the manufacturer (MTT kit I; Roche China, Ltd.). Briefly, the rat RGCs were cultured in 96-well plates, $10 \mu \mathrm{l}$ of $5 \mathrm{mg} / \mathrm{ml}$
MTT labeling reagent was added to each well containing cells in $100 \mu \mathrm{l}$ of medium, and the plate was incubated for $4 \mathrm{~h}$ in a humidified incubator at $37^{\circ} \mathrm{C}$. After the incubation, $100 \mu \mathrm{l}$ of the solvating solution $(0.01 \mathrm{~N}$ $\mathrm{HCl}$ in $10 \%$ SDS solution) was added to each well for 17-18 h. The absorbance of the samples was measured at a wavelength of $570 \mathrm{~nm}$ with $630 \mathrm{~nm}$ as a reference wavelength. Unless otherwise indicated, the extent of MTT conversion in cells exposed to glutamate is expressed as a percentage of the control.

\section{Annexin-V FITC/PI assay}

Apoptosis was detected using an Annexin-V FITC/PI detection kit (Jiancheng Biotechnology Co., Ltd., Nanjing, China) according to the manufacturer's directions. The cells were digested with $0.125 \%$ trypsin, washed with ice-cold phosphate-buffered saline and resuspended in binding buffer $\left(5 \times 10^{5}\right.$ cells $\left./ \mathrm{ml}\right)$. Then, the cells were centrifuged at $1,000 \mathrm{rpm}$ for $5 \mathrm{~min}$ at $4^{\circ} \mathrm{C}$. After the supernatant had been discarded, $500 \mu \mathrm{l}$ of binding buffer, $5 \mu \mathrm{l}$ of annexin-V-FITC and $5 \mu \mathrm{l}$ of propidium iodide (PI) were added to $200 \mu \mathrm{l}$ of the cell suspension. After mixing gently, the suspensions were incubated for $15 \mathrm{~min}$ at room temperature without light. Finally, the cells were analyzed by flow cytometry (BD LSRII; BD Biosciences).

\section{Intravitreal administration of glutamate}

Male rats (220-280 g) were anesthetized by intraperitoneal injection of $10 \%(\mathrm{w} / \mathrm{v})$ chloral hydrate $(350 \mathrm{mg} / \mathrm{kg})$ and rectal body temperature was maintained at $37^{\circ} \mathrm{C}$ with a heating pad during the experiments. The pupils were dilated with tropicamide and a single dose of $5 \mu \mathrm{l}$ of $4 \mathrm{mM}$ glutamate (total amount $20 \mathrm{nmol}$ ) in $0.01 \mathrm{M}$ PBS (pH 7.4) was injected into the vitreous cavity using 32-gauge Hamilton needle and syringe. PBS was administered as a control.

\section{TUNEL staining}

TUNEL staining was performed according to the manufacturer's protocols (In Situ Cell Death Detection Kit; Roche China, Ltd.) to detect retinal cell apoptosis induced by glutamate. Twenty-four rats were divided into eight groups: three bis(7)-tacrine-treated groups $(0.05,0.1,0.2 \mathrm{mg} / \mathrm{kg})$, three memantine-treated groups $(5,10,20 \mathrm{mg} / \mathrm{kg})$, a control group, and a glutamate group. Six eyes per experimental condition were used. In this study, $18 \mathrm{~h}$ after the glutamate injection, rats were killed with an overdose of chloral hydrate. The eyes were immediately enucleated and fixed in $4 \%$ paraformaldehyde in PBS for the TUNEL studies. The specimens were then dehydrated and embedded in paraffin and $5 \mu \mathrm{m}$ sections were cut. These sections were stained by the TUNEL method according to the manufacturer's 
directions. The yellow condensed TUNEL positive cells were counted under a $20 \times$ objective microscope. No attempt was made to distinguish the cell types in the GCL, and displaced amacrine cells were not excluded from the counts. To minimize the variance in cell number, we counted TUNEL positive cells in the retinal ganglion cell layer (GCL) manually at $1.0-2.0 \mathrm{~mm}$ (both sides) from the center of the optic disc. The average number of TUNEL positive cells/eye was obtained from three sections of each retina.

\section{Retrograde labelling and counting of RGCs}

To examine the change in the number of RGCs after glutamate injection, RGCs were retrogradely labeled with fluorogold. Twenty-four rats were treated respectively with the same division and administration above mentioned. Fifteen minutes before intravitreally injection of glutamate, drugs were intraperitoneally administered to the rats in a volume of $1.5 \mathrm{~mL} / \mathrm{kg}$ body weight. Four days after the glutamate injection, retrograde labeling of RGCs was made. Briefly, rats were anesthetized by intraperitoneally injection with $10 \%(\mathrm{w} / \mathrm{v})$ chloral hydrate $(350 \mathrm{mg} / \mathrm{kg})$ and then the heads were fixed in a stereotaxic apparatus. Fluorogold was microinjected bilaterally into the superior colliculi(SC) and dorsal lateral geniculate nuclei (dLGN) of rats. Three days after the Fluorogold injection (seven days after the glutamate injection), the animals were killed by an intraperitoneal overdose injection of chloral hydrate and the eyes were enucleated. Eyes were fixed with $4 \%$ paraformaldehyde for 1 h. Retinas were removed from the sclera, divided into four radial cuts and mounted on slides. Analysis for the number of fluorogold-labeled RGCs was carried out. Briefly, Tracer-labeled RGCs counting was performed in 12 areas of $0.072 \mathrm{~mm}^{2}$ each (three areas per retinal quadrant) at $2 / 6,3 / 6$, and $5 / 6$ of the retinal radius under a fluorescent microscope (Olympus IX71). Data from 12 areas from each eye were averaged.

\section{Statistical analysis}

Data are expressed as mean \pm SEM. Statistical significance was determined using the ANOVA method followed by Dunnett's test in the case of multiple comparisons. Single comparisons were performed by Student's t test. Statistical analysis of concentration-response data was performed using the nonlinear curve-fitting program ALLFIT, which uses an ANOVA procedure[34,51]. Values reported for concentration-response analysis are those obtained by fitting the data to the equation:

$$
Y=E_{\max } /\left[1+\left(E C_{50} / X\right)^{\mathrm{n}}\right]
$$

where $X$ and $Y$ are concentration and response, respectively, $E_{\max }$ is the maximal response, $\mathrm{EC}_{50}$ is the concentration yielding $50 \%$ of maximal effect $\left(\mathrm{EC}_{50}\right.$ for activation, $\mathrm{IC}_{50}$ for inhibition), and $\mathrm{n}$ is the slope factor.

\section{Author details}

'Department of Ophthalmology, Union Hospital, Tongji Medical College, Huazhong University of Science and Technology, Wuhan 430022, China. 2Department of Ophthalmology, The First People's Hospital of Jingzhou, Yangtze University, Jingzhou 434000, China.

\section{Authors' contributions}

JHF participated in the design of the study, carried out the cell assays and animal experiments, performed the statistical analysis, and wrote the manuscript. XHW assisted in the animal experiments and helped to draft the manuscript. ZRX assisted in the cell assays. FGJ (corresponding author) designed the study and directed the research. All authors read and approved the final manuscript.

Received: 23 October 2009

Accepted: 3 March 2010 Published: 3 March 2010

\section{References}

1. Lucas DR, Newhouse JP: The toxic effect of sodium L-glutamate on the inner layers of the retina. AMA Arch Ophthalmol 1957, 58(2):193-201.

2. Thoreson WB, Witkovsky P: Glutamate receptors and circuits in the vertebrate retina. Prog Retin Eye Res 1999, 18(6):765-810.

3. Yu W, Miller RF: The mechanism by which NBQX enhances NMDA currents in retinal ganglion cells. Brain Res 1996, 709(2):184-196.

4. Sonkusare SK, Kaul CL, Ramarao P: Dementia of Alzheimer's disease and other neurodegenerative disorders-memantine, a new hope. Pharmacol Res 2005, 51(1):1-17.

5. Sucher NJ, Lipton SA, Dreyer EB: Molecular basis of glutamate toxicity in retinal ganglion cells. Vision Res 1997, 37(24):3483-3493.

6. Osborne NN, Casson RJ, Wood JP, Chidlow G, Graham M, Melena J: Retinal ischemia: mechanisms of damage and potential therapeutic strategies. Prog Retin Eye Res 2004, 23(1):91-147.

7. Dreyer EB: A proposed role for excitotoxicity in glaucoma. J Glaucoma 1998, 7(1):62-67.

8. Kuehn $\mathrm{MH}$, Fingert $\mathrm{JH}$, Kwon $\mathrm{YH}$ : Retinal ganglion cell death in glaucoma: mechanisms and neuroprotective strategies. Ophthalmol Clin North Am 2005, 18(3):383-395, vi.

9. Pang $\mathrm{H}$, Zeng $\mathrm{H}$, Fleenor DL, Clark AF: Pigment epithelium-derived factor protects retinal ganglion cells. BMC Neurosci 2007, 8:11.

10. Inomata $\mathrm{Y}$, Hirata A, Yonemura N, Koga T, Kido N, Tanihara H: Neuroprotective effects of interleukin- 6 on NMDA-induced rat retinal damage. Biochem Biophys Res Commun 2003, 302(2):226-232

11. Calzada Jl, Jones BE, Netland PA, Johnson DA: Glutamate-induced excitotoxicity in retina: neuroprotection with receptor antagonist, dextromethorphan, but not with calcium channel blockers. Neurochem Res 2002, 27(1-2):79-88.

12. Levin LA, Peeples P: History of neuroprotection and rationale as a therapy for glaucoma. Am J Manag Care 2008, 14(1 Suppl):S11-14.

13. Lipton SA: Possible role for memantine in protecting retinal ganglion cells from glaucomatous damage. Surv Ophthalmol 2003, 48(Suppl 1): S38-46.

14. Fatma N, Kubo E, Sen M, Agarwal N, Thoreson WB, Camras CB, Singh DP: Peroxiredoxin 6 delivery attenuates TNF-alpha-and glutamate-induced retinal ganglion cell death by limiting $\mathrm{ROS}$ levels and maintaining $\mathrm{Ca}(2$ +) homeostasis. Brain Res 2008, 3;1233:63-78.

15. Brooks DE, Garcia GA, Dreyer EB, Zurakowski D, Franco-Bourland RE: Vitreous body glutamate concentration in dogs with glaucoma. Am J Vet Res 1997, 58(8):864-867.

16. Dreyer EB, Zurakowski D, Schumer RA, Podos SM, Lipton SA: Elevated glutamate levels in the vitreous body of humans and monkeys with glaucoma. Arch Ophthalmol 1996, 114(3):299-305.

17. Levin LA: Retinal ganglion cells and neuroprotection for glaucoma. Surv Ophthalmol 2003, 48(Suppl 1):S21-24.

18. Nagata T, Ueno S, Morita H, Kubota T, Toyohira Y, Tsutsui M, Tawara A, Yanagihara N: Direct inhibition of N-methyl-D-aspartate (NMDA)-receptor 
function by antiglaucomatous beta-antagonists. J Pharmacol Sci 2008, 106(3):423-434.

19. Osborne NN: Recent clinical findings with memantine should not mean that the idea of neuroprotection in glaucoma is abandoned. Acta Ophthalmol 2009, 87(4):450-454.

20. Molinaro G, Battaglia G, Riozzi B, Di Menna L, Rampello L, Bruno V, Nicoletti F: Memantine treatment reduces the expression of the $\mathrm{K}(+) / \mathrm{Cl}(-)$ cotransporter KCC2 in the hippocampus and cerebral cortex, and attenuates behavioural responses mediated by $\mathrm{GABA}(\mathrm{A})$ receptor activation in mice. Brain Res 2009, 1265:75-79.

21. Danesh-Meyer HV, Levin LA: Neuroprotection: extrapolating from neurologic diseases to the eye. Am J Ophthalmol 2009, 148(2):186-191.

22. Recommendations for standards regarding preclinical neuroprotective and restorative drug development. Stroke 1999, 30(12):2752-2758.

23. Zhao Y, Li W, Chow PC, Lau DT, Lee NT, Pang Y, Zhang X, Wang X, Han Y: Bis(7)-tacrine, a promising anti-Alzheimer's dimer, affords dose- and time-dependent neuroprotection against transient focal cerebral ischemia. Neurosci Lett 2008, 439(2):160-164

24. Netland PA, Chaturvedi N, Dreyer EB: Calcium channel blockers in the management of low-tension and open-angle glaucoma. Am J Ophthalmol 1993, 115(5):608-613.

25. Kanellopoulos AJ, Erickson KA, Netland PA: Systemic calcium channel blockers and glaucoma. J Glaucoma 1996, 5(5):357-362.

26. Neufeld AH, Sawada A, Becker B: Inhibition of nitric-oxide synthase 2 by aminoguanidine provides neuroprotection of retinal ganglion cells in a rat model of chronic glaucoma. Proc Natl Acad Sci USA 1999, 96(17):9944-9948.

27. Neufeld AH: Pharmacologic neuroprotection with an inhibitor of nitric oxide synthase for the treatment of glaucoma. Brain Res Bull 2004, 62(6):455-459.

28. Pang YP, Quiram P, Jelacic T, Hong F, Brimijoin S: Highly potent, selective, and low cost bis-tetrahydroaminacrine inhibitors of acetylcholinesterase. Steps toward novel drugs for treating Alzheimer's disease. J Biol Chem 1996, 271(39):23646-23649.

29. Wang H, Carlier PR, Ho WL, Wu DC, Lee NT, Li CP, Pang YP, Han YF: Effects of bis(7)-tacrine, a novel anti-Alzheimer's agent, on rat brain AChE. Neuroreport 1999, 10(4):789-793.

30. Li W, Pi R, Chan HH, Fu H, Lee NT, Tsang HW, Pu Y, Chang DC, Li C, Luo J, et al: Novel dimeric acetylcholinesterase inhibitor bis7-tacrine, but not donepezil, prevents glutamate-induced neuronal apoptosis by blocking N-methyl-D-aspartate receptors. J Biol Chem 2005, 280(18):18179-18188.

31. Li W, Mak M, Jiang H, Wang Q, Pang Y, Chen K, Han Y: Novel AntiAlzheimer's Dimer Bis(7)-Cognitin: Cellular and Molecular Mechanisms of Neuroprotection Through Multiple Targets. Neurotherapeutics 2009, 6(1):187-201.

32. Li W, Lee NT, Fu H, Kan KK, Pang Y, Li M, Tsim KW, Li X, Han Y: Neuroprotection via inhibition of nitric oxide synthase by bis(7)-tacrine. Neuroreport 2006, 17(5):471-474.

33. Fu H, Li W, Lao Y, Luo J, Lee NT, Kan KK, Tsang HW, Tsim KW, Pang Y, Li Z, et al: Bis(7)-tacrine attenuates beta amyloid-induced neuronal apoptosis by regulating L-type calcium channels. J Neurochem 2006, 98(5):1400-1410

34. Liu YW, Li CY, Luo JL, Li WM, Fu HJ, Lao YZ, Liu L, Pang YP, Chang DC, Li ZW, et al: Bis(7)-tacrine prevents glutamate-induced excitotoxicity more potently than memantine by selectively inhibiting NMDA receptors. Biochem Biophys Res Commun 2008, 369(4):1007-1011.

35. Luo J, Li W, Liu Y, Zhang W, Fu H, Lee NT, Yu H, Pang Y, Huang P, Xia J, et al: Novel dimeric bis(7)-tacrine proton-dependently inhibits NMDAactivated currents. Biochem Biophys Res Commun 2007, 361(2):505-509.

36. Otori $Y$, Wei JY, Barnstable CJ: Neurotoxic effects of low doses of glutamate on purified rat retinal ganglion cells. Invest Ophthalmol Vis Sci 1998, 39(6):972-981.

37. Linden $R$, Esberard CE: Displaced amacrine cells in the ganglion cell layer of the hamster retina. Vision Res 1987, 27(7):1071-1076.

38. Kawasaki A, Han MH, Wei JY, Hirata K, Otori Y, Barnstable CJ: Protective effect of arachidonic acid on glutamate neurotoxicity in rat retinal ganglion cells. Invest Ophthalmol Vis Sci 2002, 43(6):1835-1842.

39. Li W, Xue J, Niu C, Fu H, Lam CS, Luo J, Chan HH, Xue H, Kan KK, Lee NT, et al: Synergistic neuroprotection by bis(7)-tacrine via concurrent blockade of $\mathrm{N}$-methyl-D-aspartate receptors and neuronal nitric-oxide synthase. Mol Pharmacol 2007, 71(5):1258-1267.
40. Kawasaki A, Otori Y, Barnstable CJ: Muller cell protection of rat retinal ganglion cells from glutamate and nitric oxide neurotoxicity. Invest Ophthalmol Vis Sci 2000, 41(11):3444-3450.

41. Li Z, Hua Y, Ming LW, Chun CM, Ping PY, Ge L, Tao WY, Zhong Z, Fan HY: Selective and sensitive determination of bis(7)-tacrine, a high erythrocyte binding acetylcholinesterase inhibitor, in rat plasma by high-performance liquid chromatography-tandem mass spectrometry. Biomed Chromatogr 2008, 22(4):414-420.

42. Yu H, Ho JM, Kan KK, Cheng BW, Li WM, Zhang L, Lin G, Pang YP, Gu ZM, Chan K, et al: Development of a high performance liquid chromatography-tandem mass method for determination of bis(7)tacrine, a promising anti-Alzheimer's dimer, in rat blood. J Pharm Biomed Anal 2007, 44(5):1133-1138.

43. Brandstatter JH, Hartveit E, Sassoe-Pognetto M, Wassle H: Expression of NMDA and high-affinity kainate receptor subunit mRNAs in the adult rat retina. Eur J Neurosci 1994, 6(7):1100-1112.

44. Costenla AR, De Mendonca A, Sebastiao A, Ribeiro JA: An adenosine analogue inhibits NMDA receptor-mediated responses in bipolar cells of the rat retina. Exp Eye Res 1999, 68(3):367-370.

45. Muir KW, Grosset DG: Neuroprotection for acute stroke: making clinical trials work. Stroke 1999, 30(1):180-182.

46. Hickenbottom SL, Grotta J: Neuroprotective therapy. Semin Neurol 1998, 18(4):485-492.

47. Volbracht C, van Beek J, Zhu C, Blomgren K, Leist M: Neuroprotective properties of memantine in different in vitro and in vivo models of excitotoxicity. Eur J Neurosci 2006, 23(10):2611-2622.

48. Gilling KE, Jatzke C, Hechenberger M, Parsons CG: Potency, voltagedependency, agonist concentration-dependency, blocking kinetics and partial untrapping of the uncompetitive N-methyl-D-aspartate (NMDA) channel blocker memantine at human NMDA (GluN1/GluN2A) receptors. Neuropharmacology 2009, 56(5):866-875.

49. Chen HS, Lipton SA: Mechanism of memantine block of NMDA-activated channels in rat retinal ganglion cells: uncompetitive antagonism. J Physiol 1997, 499(Pt 1):27-46.

50. Liu J, Ho W, Lee NT, Carlier PR, Pang Y, Han Y: Bis(7)-tacrine, a novel acetylcholinesterase inhibitor, reverses AF64A-induced deficits in navigational memory in rats. Neurosci Lett 2000, 282(3):165-168.

51. Liu YW, Luo JL, Ren H, Peoples RW, Ai YX, Liu LJ, Pang YP, Li ZW, Han YF, Li CY: Inhibition of NMDA-gated ion channels by bis(7)-tacrine: wholecell and single-channel studies. Neuropharmacology 2008, 54(7):1086-1094.

doi:10.1186/1471-2202-11-31

Cite this article as: Fang et al:: Neuroprotective effects of bis(7)-tacrine against glutamate-induced retinal ganglion cells damage. $B M C$ Neuroscience 2010 11:31.

\section{Submit your next manuscript to BioMed Central and take full advantage of:}

- Convenient online submission

- Thorough peer review

- No space constraints or color figure charges

- Immediate publication on acceptance

- Inclusion in PubMed, CAS, Scopus and Google Scholar

- Research which is freely available for redistribution

Submit your manuscript at www.biomedcentral.com/submit
C Biomed Central 